\title{
Preparation of CdS Thin Films through MOCVD Method, Using Cd-S Single-source Precursors
}

\author{
Seok Hwan Yoon, Seung Soo Lee, Kook Won Seo, and II-Wun Shim \\ Deparment of Chemistry, Chtmg-Ang Lniversity, Seoul 156-756, Korea. ${ }^{\circ}$ E-mail: iwshimacau.ac.kr \\ Received June 30,2006
}

Key Words : MOCVD. CdS thin film. CdS single source precursors

Thin films of cadnium sulfide (CdS) have been used as a hetero-junction window layer in the fabrication of semiconductor based solar cells such as CdTe. InP, CuIn $\mathrm{Cu}_{1-x} \mathrm{Ga}_{x} \mathrm{Se}_{2}$. and $\mathrm{Cu}_{-} \mathrm{S}^{1-4}$ since $\mathrm{CdS}$ has a relatively wide band gap energy $(\mathrm{Eg}=2.42-2.45 \mathrm{eV})^{5}$ and possesses n-type semiconductor characteristics. Recently. CdS is also applied to dye-sensitized photoelectrochenical cells to improve their performance. ${ }^{6}$ Numerous physical properties of CdS films notably depend on their deposition methods and the particular conditions of preparation processes. They can be prepared by chemical. physical and electrochenical methods such as molecular bean epitaxy (MBE): metal organic chenical vapor deposition (MOCVD); close-spaced sublination (CSS): chemical bath deposition (CBD); electro-deposition; successive ionic layer adsorption and reaction (SILAR): screen printing: pulsed laser ablation; RF sputtering: and spray pyrolysis. ${ }^{7}$ Among them, the MOCVD technique has received much attention due to its great potential application to the fabrication of high-quality layers. Though there are several different kinds of precursors for MOCVD process. the use of a single-source precursor provides a novel approach to the deposition of $\mathrm{CdS}$ films with many benefits to reduce deposition temperatures and avoid the use of hazardous metal alkyls, $\mathrm{H}_{2} \mathrm{~S}$, or alkyl sulfide ${ }^{\mathrm{S}}$ Also, the precursors containing dithiocarbanate ligands with asymmetrical dialkỵl groups were interesting since they were found to have relatively lower melting and/or decomposition temperatures than those of symmetrical ones.

In this work. new $\mathrm{Cd}-\mathrm{S}$ single source precursors were synthesized with high purity and high yield. Using them. CdS thin films were successfully deposited through MOCVD method on various substrates such as glass. ITO/glass. $\mathrm{CuLn}_{-x} \mathrm{Ga}_{x} \mathrm{Se}_{2}(\mathrm{CIGS}) /$ glass and $\mathrm{TiO}_{2} / \mathrm{TO} /$ glass. and were characterized by various spectroscopic methods.

\section{Experimental Section}

General. NMR spectra were recorded on Varian Gemini 2000 NMR spectrometer. Infrared spectra were obtained on Jasco FT/IR-5300 spectrometer and mass spectra were obtained on Autospec EBE mass spectrometer. Thermal analyses including TGA and DSC were carried out with Setaran LABSYS for the characterization of synthesized precursors. For the analyses of CdS thin filnts. Scintag XDS $2000 \mathrm{x}$-ray diffractometer (XRD). I.S.I.-DS 130, and Philips
XL30S FEG scanning electron microscope equipped with a Phoenix energy dispersive $x$-ray spectrometer (SEM-EDAX) were used. The optical band gap energy was measured by UV/Vis spectroscopy (JASCO U-550).

Synthesis of ColS single source precursors: Three cadmium(II)dithiocarbamate precursors were synthesized by reacting cadmium hydroxide (10 mmol). three different secondary amines (20 mmol) and carbon disulfide (20 mmol) in a $100 \mathrm{~mL}$ boiling methanol solution. as described in other researches. ${ }^{\text {lit-12 }}$ After a l hour reaction, ivory-colored precipitates was obtained. These precipitates were filtered by glass filter and recrystallized with cold methylene chloride and ethanol. The final product was dried under vacuum at room temperature.

Synthesis of $\operatorname{Cd}(N, N \text {-diethyldithiocarbamate })_{2}$ : this precursor $^{8}$ with symmetric alkyl groups was synthesized with diethyl amine (Aldrich. $1.47 \mathrm{~g}$. $20 \mathrm{mmol}$ ) for a comparative study to those with asymmetric alkyl groups; yield $72 \%$; white powder; EI-MS $\mathrm{m} / \mathrm{z}(70 \mathrm{eV}) 410\left(\mathrm{M}^{+}\right)$; ${ }^{1} \mathrm{H}$ NMR $\left(300 \mathrm{MHz} . \mathrm{CDCl}_{3}\right) \delta 1.34$ (t. 6H), 3.93 (q. 4H): FT-IR ( $\mathrm{KBr}$ pellet) $v(\mathrm{C}-\mathrm{N}) 1498 . v\left(\mathrm{~N}-\mathrm{CS}_{2}\right) 143 \mathrm{l}, v(\mathrm{C}-\mathrm{S}) 992 \mathrm{~cm}^{-1}$. elemental analysis (calcd. C 29.4, H 4.9, N 6.9\%) C 29.0 . H 4.8. N 6.8\%.

Synthesis of $\mathrm{Cd}(N, N \text {-ehylbuthyldithiocarbamate })_{2}$; this asymmetric precursor was synthesized with N-ethylbytyl amine (Aldrich, $2.04 \mathrm{~g}, 20$ mmol); yield $90 \%$ : white powder; EI-MS n/z (70 eV) $466\left(\mathrm{M}^{-}\right)$: ${ }^{1} \mathrm{H}$ NMR $\left(300 \mathrm{MHz} . \mathrm{CDCl}_{3}\right)$ $\delta 0.95$ (t. 3H). 1.36 (m. 2H). 1.78 (m. $2 \mathrm{H}$ ), 3.83 (t. $2 \mathrm{H}$ ). 1.35 (t. 3H). 3.92 (q. 2H); FT-IR (KBr pellet) $v(\mathrm{C}-\mathrm{N}) 1503.1493$, $v$ (N-CS:) $1425, v(\mathrm{C}-\mathrm{S}) 996 \mathrm{~cm}^{-1}$. elemental analysis (calcd. C 36.2, H 6.1. N 6.0\%) C 36.1. H 6.0. N 6.0\%.

Synthesis of $\mathbf{C d}(2$-ethylpiperidinedithiocarbamate) this cyclic asymmetric precursor was synthesized with 2ethylpiperidine (Aldrich, 2.35 g. 20 mmol); yield $78 \%$. white powder: EI-MS m/z $(70 \mathrm{eV}) 490\left(\mathrm{M}^{+}\right)$; ${ }^{1} \mathrm{H}$ NMR (300 $\left.\mathrm{MHz}, \mathrm{CDCl}_{3}\right) \delta 0.95$ (t. 3H), 1.58 (m. $2 \mathrm{H}$ ). 1.65 (m. $2 \mathrm{H}$ ), 1.72 (m. 2H). $1.81(\mathrm{~m}, 2 \mathrm{H}), 3.14(\mathrm{~m}, \mathrm{lH}), 5.19$ (m. $\mathrm{lH}) .5 .35$ (m, IH): FT-IR (KBr pellet) $v(\mathrm{C}-\mathrm{N}) 1471,1447 . v(\mathrm{~N}-\mathrm{CS})$ 1432. $v(\mathrm{C}-\mathrm{S}) 989 \mathrm{~cm}^{-1}$; elemental analy sis (calcd. C $39.3, \mathrm{H}$ $5.8, \mathrm{~N} 5.7 \%$ ) C $38.7, \mathrm{H} \mathrm{5.7.} \mathrm{N} 5.6 \%$.

Film depositions: $\mathrm{CdS}$ thin films were prepared with the three precursors through MOCVD method. The bubblertype glass warm wall MOCVD reactor was used. In the case of $\mathrm{Cd}\left[\mathrm{S}_{2} \mathrm{CN}\left(\mathrm{C}_{2} \mathrm{H}_{5}\right)\left(\mathrm{C}_{4} \mathrm{H}_{9}\right)\right]_{2}$ as a precursor, bubbler temperature was $170^{\circ} \mathrm{C}$. substrate temperature was $350-440^{\circ} \mathrm{C}$. 
and deposition time was 1-4 hr. In the other case of $\mathrm{Cd}\left[\mathrm{S}_{2} \mathrm{CN}\left(\mathrm{C}_{7} \mathrm{H}_{14}\right)\right]$, bubbler temperature was $220^{\circ} \mathrm{C}$. substrate temperature was $330-410^{\circ} \mathrm{C}$, and deposition time was $2 \mathrm{hr}$. In each case base pressure was 1 mtorr and working pressure was 100 mtorr. Both asymmetric precursors gave rise to CdS thin films with same quality. Ar gas was used for a carrier gas with $20 \mathrm{sccm}$ flow rate. Various substrates such as glass. ITO/glass. $\mathrm{TiO}_{2} / \mathrm{TOO} /$ glass, and $\mathrm{CuIn}_{]_{x}} \mathrm{Ga}_{3} \mathrm{Se}_{2}$ (CIGS) /glass were used to examine their applicability for the preparation to thin film solar cells.

\section{Results and Discussion}

The synthesized precursors. $\mathrm{Cd}\left[\mathrm{S}_{-} \mathrm{CN}\left(\mathrm{C}_{2} \mathrm{H}_{5}\right)\left(\mathrm{C}_{4} \mathrm{H}_{5}\right)\right]_{2}$ and $\mathrm{Cd}\left[\mathrm{S}_{2} \mathrm{CN}\left(\mathrm{C}_{7} \mathrm{H}_{14}\right)\right]_{2}$, are air stable and also thermally stable without decomposition even at quite high temperature above their melting points. The results of themo-gravimetric analyses (TGA) conducted at atmosphere pressure under an argon purge are listed in Table 1. It is noteworthy that the meltung point range of $\mathrm{Cd}\left[\mathrm{S}_{2} \mathrm{CN}\left(\mathrm{C}_{2} \mathrm{H}_{5}\right)\left(\mathrm{C}_{4} \mathrm{H}_{5}\right)\right]_{2}$ is quite lower than that of any other $\mathrm{Cd}-\mathrm{S}$ single source precursors: it was even lower than that of $\mathrm{Cd}\left[\mathrm{S}_{2} \mathrm{CN}\left(\mathrm{C}_{2} \mathrm{H}_{5}\right)_{2}\right]$. Such low melting is believed to arise from the asymmetric aliphatic groups of the precursor. resulting in less compact packing in solid state. In this respect. $\mathrm{Cd}\left[\mathrm{S}_{2} \mathrm{CN}_{2}\left(\mathrm{C}_{2} \mathrm{H}_{5}\right)\left(\mathrm{C}_{4} \mathrm{H}_{5}\right)\right]_{2}$ could be better precursor that can be processed at lower operatung condition. In the case of $\mathrm{Cd}\left[\mathrm{S}_{2} \mathrm{CN}\left(\mathrm{C}_{7} \mathrm{H}_{4}\right)_{2}\right]_{2}$ precursor, it has a relatively very low decomposition temperature than any other similar precursors. This result can be ascribed to its cyclic moiety. making the thermal decomposition process easier. ${ }^{13}$

$\mathrm{XRD}$ patterns and SEM images of prepared $\mathrm{CdS}$ thin films from $\mathrm{Cd}\left[\mathrm{S}_{2} \mathrm{CN}\left(\mathrm{C}_{2} \mathrm{H}_{5}\right)\left(\mathrm{C}_{4} \mathrm{H}_{9}\right)\right]$ : precursor on ITO/glass substrate were shown in Figure 1. These XRD pattens show that prepared $\mathrm{CdS}$ has a hexagonal crystal structure ${ }^{1+}$ In Figure 1. the intensities of the peaks of (002) and (103) and the particle sizes of the films increase as the substrate temperature mereases. The film growth rate measured by the thickness of the films was $8 \mathrm{~nm} / \mathrm{min}$ at $410^{\circ} \mathrm{C}$. indicating that the film growing process is very efficient. EDX analy ses show that the ratios of $\mathrm{S} / \mathrm{Cd}$ of deposited films vary from nearly 1.02 to 0.87 at the substrate temperature range of $350-$ $410^{\circ} \mathrm{C}$. The $\mathrm{Cd}$ and $\mathrm{S}$ ratio was exactly $\mathrm{I}: \mathrm{I}$ at the substrate temperature about $360^{\circ} \mathrm{C}$, revealing that the $\mathrm{Cd} / \mathrm{S}$ ratio can be controlled by the substrate temperature. Also. there was

Table 1. Physical properties of synthesized CdS precursors

\begin{tabular}{|c|c|c|c|c|}
\hline Ptecursors & State & $\begin{array}{l}\text { Air and } \\
\text { thermal } \\
\text { stability }\end{array}$ & $\begin{array}{c}\text { Melting } \\
\text { point } \\
(\mathrm{C})\end{array}$ & $\begin{array}{c}\text { Decomposition } \\
\text { temperature } \\
\left({ }^{\circ} \mathrm{C}\right)\end{array}$ \\
\hline$\overline{\mathrm{Cd}\left[\mathrm{S}_{2} \mathrm{CN}\left(\mathrm{C}_{2} \mathrm{H}_{3}\right)_{2}\right]_{2}}$ & $\begin{array}{l}\text { white } \\
\text { powder }\end{array}$ & stable & $248-259$ & 337 \\
\hline $\mathrm{Cd}\left[\mathrm{S}_{2} \mathrm{CN}\left(\mathrm{C}_{2} \mathrm{H}_{3}\right)\left(\mathrm{C}_{4} \mathrm{H}_{4}\right)\right]=$ & $\begin{array}{l}\text { white } \\
\text { powder }\end{array}$ & $\begin{array}{l}\text { very } \\
\text { stable }\end{array}$ & $111-12 \hat{3}$ & 340 \\
\hline $\mathrm{Cd}\left[\mathrm{S}_{2} \mathrm{CN}\left(\mathrm{C}_{-} \mathrm{H}_{11}\right)\right]_{2}$ & $\begin{array}{l}\text { white } \\
\text { powder }\end{array}$ & stable & $209-226$ & 311 \\
\hline
\end{tabular}

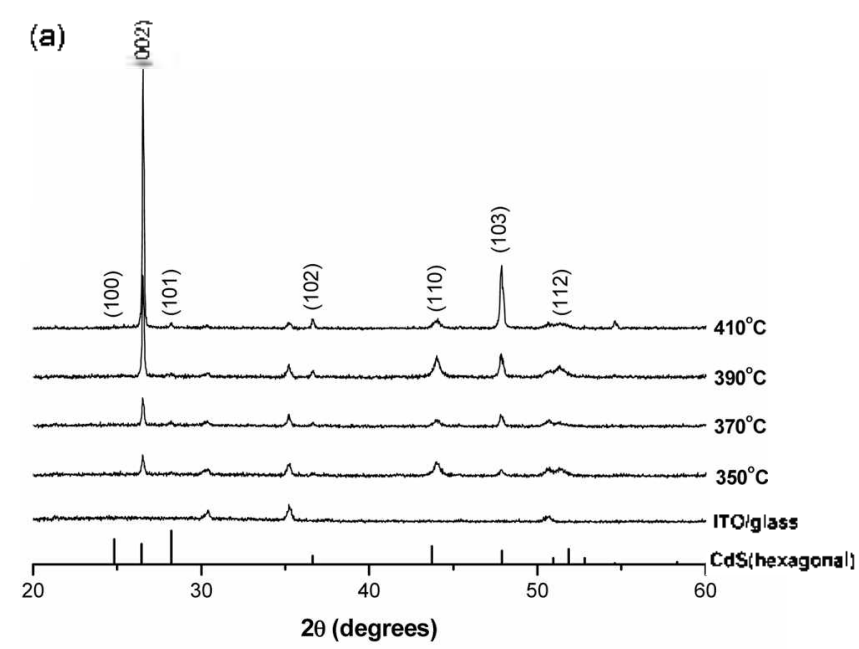

(b)
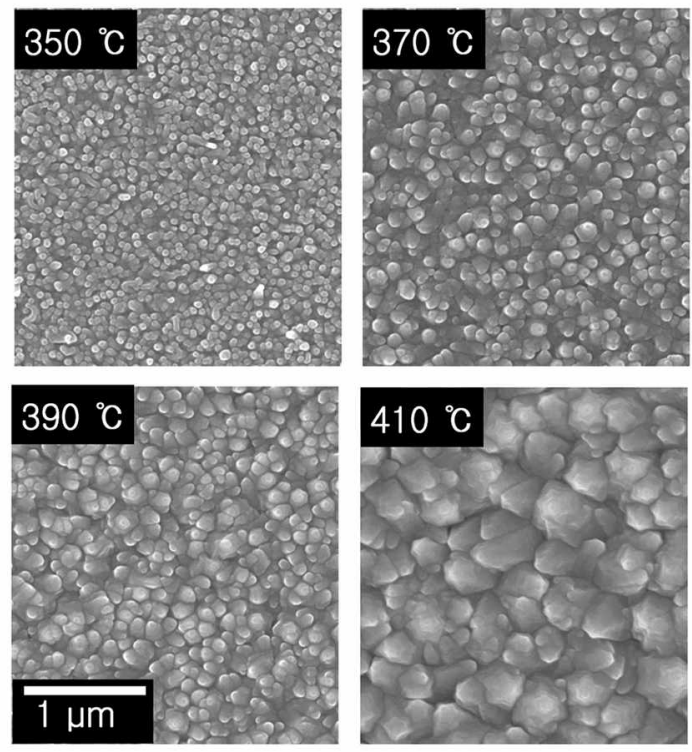

Figure 1. (a) X-ray diffraction patterns and (b) SEM images of CdS thin films on ITO/glass substrate at different substrate temperatures from $\mathrm{Cd}\left[\mathrm{S}_{2} \mathrm{CN}\left(\mathrm{C}_{2} \mathrm{H}_{5}\right)\left(\mathrm{C}_{4} \mathrm{H}_{4}\right)\right]_{2}$ precursor.
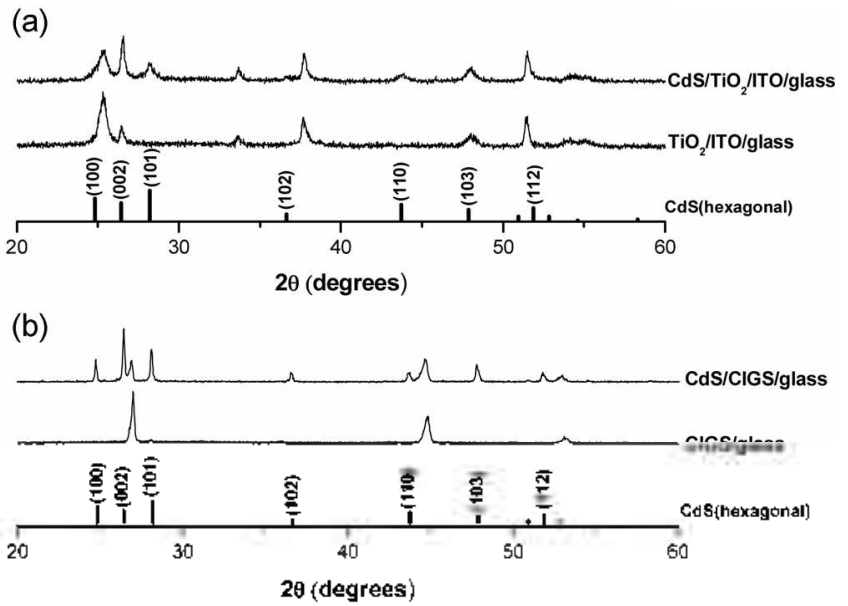

Figure 2. X-ray diffraction pattens of CdS thin films on (a) $\mathrm{TiO}_{2} /$ glass substrate and (b) CuIn ${ }_{1-X} \mathrm{Ga}_{3} \mathrm{Se}_{2}$ (CIGS)/glass substrate at $4 \mathrm{l} 0$ c. 
(a)
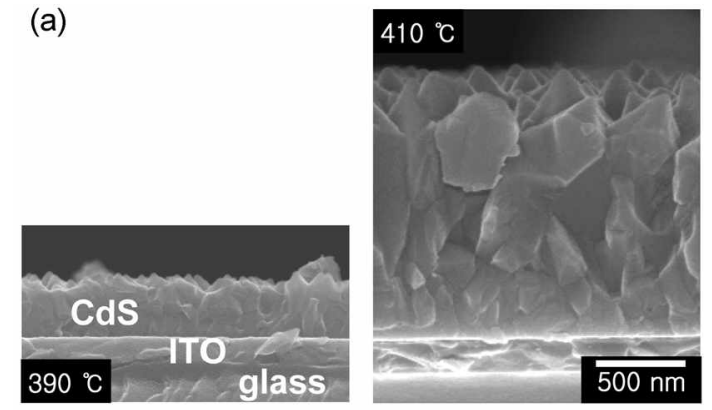

(b)
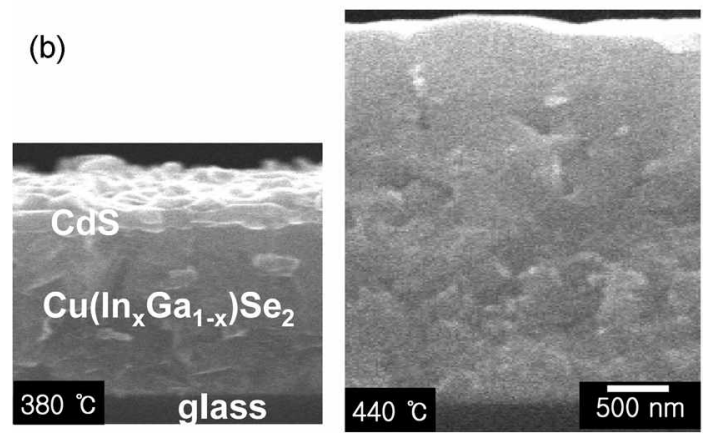

Figure 3. Cross section SEM inages of CAS thin films on (a) ITO/ glass substrate and (b) CIGS/glass substrate.

no evidence for the appreciable amounts of impurities such as carbide nitride and oxide in the films.

In addition. CdS thin films could be easily deposited on $\mathrm{TiO}_{2}$ and $\mathrm{CIGS}$ film as shown in Figure 2. In the case of CIGS substrate. however. there was a significant intermixing between the two layers at above $440^{\circ} \mathrm{C}$ as shown in Figure 3. Therefore for the CIGS/glass substrate. the CdS film should be deposited below $440^{\circ} \mathrm{C}$.

$\mathrm{CdS}$ films with $\mathrm{Cd}\left[\mathrm{S}_{2} \mathrm{CN}\left(\mathrm{C}_{7} \mathrm{H}_{44}\right)_{2}\right.$ l: were deposited on glass substrate at the bubbler temperature of $220{ }^{\circ} \mathrm{C}$. The growth rate of $\mathrm{CdS}$ thin films was $3 \mathrm{~nm} / \mathrm{min}$ when the substrate temperature was $370^{\circ} \mathrm{C}$. This result is interesting since. in the case of $\mathrm{Cd}\left[\mathrm{S}_{2} \mathrm{CN}\left(\mathrm{C}_{2} \mathrm{H}_{3}\right)\left(\mathrm{C}_{4} \mathrm{H}_{9}\right)\right]_{2}$. the growth rate of CdS thin film was $1 \mathrm{~nm} / \mathrm{min}$ at the same condition. This relatively high growth rate is assumed to arise from the lower decomposition temperature of the precursor. Besides. it is noteworthy that though the $\mathrm{Cd}\left[\mathrm{S}_{2} \mathrm{CN}\left(\mathrm{C}_{3} \mathrm{H}_{3}\right)_{2}\right]_{2}$ precursor was tried to make $\mathrm{CdS}$ thin film at the similar conditions as above but the quality of films was very poor. At this stage. the reason is not clear.

In conclusion. $\mathrm{Cd}\left[\mathrm{S}_{2} \mathrm{CN}\left(\mathrm{C}_{2} \mathrm{H}_{5}\right)\left(\mathrm{C}_{4} \mathrm{H}_{3}\right)\right]_{2}$ and $\mathrm{Cd}\left[\mathrm{S}_{2} \mathrm{CN}-\right.$ $\left.\left(\mathrm{C}_{7} \mathrm{H}_{14}\right)_{2}\right]_{2}$ precursors were synthesized for bubbler type MOCVD process with high yields and characterized by various spectroscopic methods. $\mathrm{Cd}\left[\mathrm{S}_{2} \mathrm{CN}\left(\mathrm{C}_{2} \mathrm{H}_{5}\right)\left(\mathrm{C}_{4} \mathrm{H}_{0}\right)\right]_{2}$ with asymmetric ligand structure has the lowest melting point among the known $\mathrm{Cd}-\mathrm{S}$ single source precursors. In the case of $\mathrm{Cd}\left[\mathrm{S}_{2} \mathrm{CN}\left(\mathrm{C}_{7} \mathrm{H}_{44}\right)_{2}\right]$ : having asymmetric cyclic ligand. its decomposition temperature were found to be quite low in comparison to the similar precursors. Using these precursors. highly pure CdS thin films were prepared on various substrates such as glass. ITO/glass and CIGS/glass substrates under relatively mild conditions with high growth rate. The optical band gap energy of the obtained CdS thin film was about $2.44 \mathrm{eV}$. suggesting that these precursors could be adopted as a polycrystalline CdS window layer through MOCVD process for the CIGS type solar cells.

Acknowledgement. This research was supported by the Chung-Ang University Research Grant in 2006.

\section{References}

1. Tavina, T. V.: Rogacheva, E. I. d. Phys. Chem. Solids $\mathbf{2 0 0 3}, 64$. 1917.

2. Durose. K.: Edwards. P. R.: Halliday. D. P. J. Crnst. Growth 1999. 197. 733 .

3. Boer. K. W. J. Crist. Growth 1982.59. 111.

4. Shanthi. S.: Subramanaian. C.: Ramasamy. P. Mater Chent. Phus. 1999. $58,4.4$.

5. Bloor. D.: Brook. R. J: Flemings, M. C: Mahajan. S. The Encyclopedia of Adwanced Materials; Elsevier Science Ltd: 1994: Vol 1.p 301.

6. Bandaranayake. P. K. M.: Tayaweera. P. V. V: Tennakone. K. Sol. Energ. Mat. Sol. C 2003. 76.57 .

7. Oliva A. I.; Castro-Rodnguez, R: Solis-Canto. O.: Sosa. V: Quintana. P.: Peña. J. L. Appl. Surf. Sci. 2003. 205. 56.

8. O'Brien. P: Malik. M. A:C Chunggaze. M: Trindade. T: Walsh. J. R. Jones. A. C. J. Cnst. Grow 1997.170.23.

9. Fainer. N. I.: Kosinova. M. L.: Rumyantsey. Y. U.: Salmant. E. G.: Kuznetsor. F. A. Thim Solid Films 1996. 280. 16.

10. Seo. K. W; Yoon. S. H.: Lee, S. S; Shim, I-W. Bull. Konam Chem. Soc. 2005, 26. 1582.

11. Monteiro. O. C.: Trindade. T: Park. J.-H.; O'Brien. P. Aater: Lett 2003. 58.119

12. Lee. S. S.: Yoon. S. H.: Seo. K. W.: Shim. I.W. Bull Konan Chent. Soc. 2005. 26. 1453

13. Sharma. A. K. Thermodim. Acta 1986. 104, 339.

14. JCPLS Cards 1995. No. 06-0314. 